\title{
Potential role for peroxisome proliferator activated receptor (PPAR) in preventing colon cancer
}

\author{
L Jackson, W Wahli, L Michalik, S A Watson, T Morris, K Anderton, D R Bell, J A Smith, \\ C J Hawkey, A J Bennett
}

Gut 2003;52:1317-1322

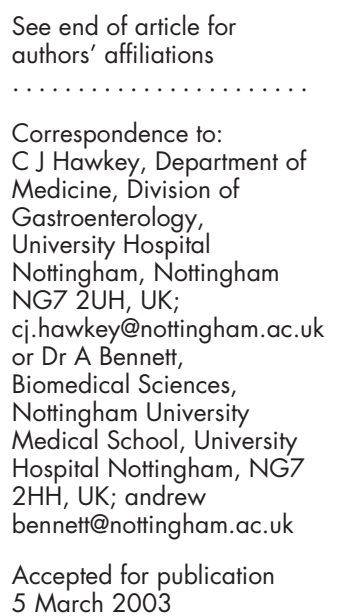

Background: Peroxisome proliferator activated receptors (PPARs) are nuclear hormone receptors involved in genetic control of many cellular processes. PPAR and PPAR have been implicated in colonic malignancy. Here we provide three lines of evidence suggesting an inhibitory role for PPAR in colorectal cancer development.

Methods: Levels of PPAR mRNA and protein in human colorectal cancers were compared with matched non-malignant mucosa using RNAse protection and western blotting. $\mathrm{APC}^{\mathrm{Min}} /+$ mice were randomised to receive the PPAR activator methylclofenapate $25 \mathrm{mg} / \mathrm{kg}$ or vehicle for up to 16 weeks, and small and large intestinal polyps were quantified by image analysis. The effect of methylclofenapate on serum stimulated mitogenesis (thymidine incorporation), linear cell growth, and annexin $V$ and propidium iodide staining were assessed in human colonic epithelial cells.

Results: PPAR (mRNA and protein) expression levels were significantly depressed in colorectal cancer compared with matched non-malignant tissue. Methylclofenapate reduced polyp area in the small intestine from $18.7 \mathrm{~mm}^{2}$ (median (interquartile range $\left.11.1,26.8\right)$ ) to $9.90(4.88,13.21) \mathrm{mm}^{2}$ $(p=0.003)$ and in the colon from $9.15(6.31,10.5) \mathrm{mm}^{2}$ to $3.71(2.71,5.99) \mathrm{mm}^{2}(p=0.009)$. Methylclofenapate significantly reduced thymidine incorporation and linear cell growth with no effect on annexin $\mathrm{V}$ or propidium iodide staining.

Conclusions: PPAR may inhibit colorectal tumour progression, possibly via inhibition of proliferation, and may be an important therapeutic target.
C olorectal cancer is the fourth commonest form of cancer occurring worldwide, with an estimated 783000 new cases diagnosed in 1990, ${ }^{1}$ and is responsible for $7.2 \%$ of all cancer deaths worldwide. ${ }^{2}$ A moderately predictable evolution of oncogenic transformation is recognised ${ }^{3}{ }^{4}$ but as yet little current understanding has translated into therapeutic gain. Among the most promising approaches to chemoprevention are the use of aspirin or non- aspirin non-steroidal antiinflammatory drugs (NSAIDs) or inducible cyclooxygenase (COX) - 2 inhibitors. However, toxicity and cost considerations may limit application at a population level. Moreover, how such chemopreventative strategies work, whether there are common or multiple mechanisms, and how interactions with oncogenic expression take place are all far from clear.

Peroxisome proliferator activated receptors (PPARs) are ligand activated nuclear transcription factors first recognised for their role in rodent livers ${ }^{5}$ where they mediate the proliferative response of peroxisomes to various compounds. Since their identification, it has become clear that PPARs play a much wider and central role in orchestrating gene expression in response to exogenous ligands. In particular, they have an intimate two way relationship with NSAIDs. PPAR activation can lead to altered expression of COX-2, ${ }^{67}$ while NSAIDs have been reported to be capable of activating PPARs. ${ }^{8}$ In addition, NSAIDs, through effects on COX activity, can alter synthesis of eicosanoids that may bind to and act as ligands for PPARs. ${ }^{910}$ In addition, NSAIDs have themselves been reported to inhibit DNA binding activity of PPARs with apparent functional consequences such as induction of apoptosis. ${ }^{11}$

Much attention has focused on the role of the different PPARs in the human intestine, in particular on their importance in neoplastic transformation. PPAR $\beta$ and to a lesser degree PPAR $\gamma$ have been proposed as possible promoters of colorectal carcinoma. ${ }^{11-13}$ Less attention has been paid to PPAR $\alpha$, probably because of a relatively lower baseline expres- sion level of this isotype in non-malignant human colonic mucosa. ${ }^{14}$ Although PPAR $\alpha$ ligands appear to promote expression of COX-2 in animals, ${ }^{6}$ human studies suggest that PPAR $\alpha$ may act conversely and inhibit COX-2 expression. ${ }^{7}$ PPAR $\alpha$ is activated by the omega- 3 fatty acid constituents of fish oil diet which have been demonstrated both to reduce colorectal cancer progression in various animal models $\mathrm{s}^{15-17}$ and to reduce cellular proliferation rates in colorectal mucosa of patients with familial adenomatous polyposis. ${ }^{18}$ PPAR $\alpha$ activation may thus be potentially beneficial in preventing colon cancer. This hypothesis is supported by the more recent study of Tanaka et al which demonstrated that bezafibrate, a PPAR $\alpha$ ligand, inhibited azoxymethane induced aberrant crypt foci formation in rats. ${ }^{19}$

In order to understand further the biology of PPAR $\alpha$ in human colorectal function and its possible role in malignant pathology, we compared expression of PPAR $\alpha$ in nonmalignant and malignant colonic mucosa, activation by ligands, and the potential value of these ligands in preventing colorectal cancer in the $A P C^{\text {Min }} /+$ mouse model of familial adenomatous polyposis.

\section{MATERIALS AND METHODS \\ Chemicals}

Methylclofenapate (synthesised by Lancaster Synthesis Ltd, Lancashire, UK) was a kind gift from Dr CR Elcombe. We purchased Wy 14643 from Biomol (Affinity Research Products

Abbreviations: NSAIDs, non-steroidal anti-inflammatory drugs; COX, cyclooxygenase; PPAR, peroxisome proliferator activated receptor; IQR, interquartile range. 
Ltd, Mamhead, Exeter, UK). We obtained radiolabelled chemicals from Amersham International, UK. Unless otherwise stated, we obtained other compounds from Sigma (UK).

\section{Plasmids}

The reporter plasmid PPRE-tk Luc, a kind gift from Dr R Evans (Salk Institute), has previously been described, and contains three copies of the acyl-coA oxidase PPRE upstream of the herpes virus thymidine promoter. ${ }^{8}$ We obtained human PPARo in pBK-CMV (1731 bp), used for RNAse protection assays, from the Image Consortium Library. pSG5-xPPAR $\beta$ and pSG5-xPPAR $\gamma$ expression plasmids constructed by insertion of the entire xPPAR $\beta$ and $x P P A R ~ \gamma$ DNAs as EcoRI fragments into pSG $5^{20}$ have previously been described and were used for transfection studies, as was pSG5-mPPAR $\alpha$ expression plasmid, a kind gift from Dr S Green. ${ }^{21}$ pSG5 empty vector and pRL-CMV were purchased from Promega (Southampton, UK).

\section{Comparison of PPAR expression in non-malignant and neoplastic mucosa \\ Tissue sampling}

We obtained mucosal biopsies samples from tumour, and from macroscopically non- malignant mucosa $>3 \mathrm{~cm}$ from the tumour, in 26 randomly selected patients undergoing resection. Biopsy samples were immediately frozen in liquid nitrogen and stored at $-70^{\circ} \mathrm{C}$ until RNA preparation and/or protein extraction. We confirmed the benign or malignant status of all samples histologically.

\section{RNA quantification}

We extracted RNA from frozen tissue samples using standard techniques $^{22}$ and quantification was performed using a ribonuclease (RNAse) protection assay. Using this technique, labelled RNA probe complementary to target RNA is mixed with sample RNA, and the complementary transcripts hybridise and unhybridised probe is then degraded by the addition of ribonuclease. The protected probe is then run on a gel and visualised by autoradiography.

\section{Construction of PPARa probe for RNAse protection assay}

Human PPAR $\alpha 263$ corresponding to nucleotides 721-983 of the cDNA sequence was excised using restriction enzymes EcoRI and PstI, inserted into pBluescriptllKS (Stratagene, La Jolla, California, USA) with the $5^{\prime}$ end adjacent to the T3 promoter, and sequenced to confirm identity.

\section{RNAse protection assay}

We synthesised labelled RNA transcripts from the inserts with $\left[\alpha^{32}-\mathrm{P}\right.$ CTP] as the limiting nucleotide using the Stratagene RNA Transcription Kit. We linearised PPAR $\alpha 263$ with PstI and prepared antisense cRNA using T3 polymerase. We performed the RNAse protection assay using the Ambion Ribonuclease Protection Assay kit (RPAl1). We hybridised $40 \mu \mathrm{g}$ of total RNA (tumour and matching non-malignant colonic mucosa) with cRNA ( $100000 \mathrm{cpm})$ overnight at $42^{\circ} \mathrm{C}$. We digested the unhybridised probe with RNAse $\mathrm{A} / \mathrm{Tl}$, as described in the manufacturer's instructions, and resolved the protected fragments on a $6 \%$ urea/acrylamide/TBE gel. Bands were imaged using a Fujix Bas 2000 phosphoimager (Fuji, Japan), and quantitated using AIDA software. Results were normalised using oligo $\mathrm{dT}_{18}$ hybridisation, as previously described. ${ }^{23}$

\section{Western blot analysis of PPAR $\alpha$}

We extracted protein from non-malignant or malignant mucosa, as previously described. ${ }^{24}$ We separated $90 \mu \mathrm{g}$ of protein by sodium dodecyl sulphate-polyacrylamide gel electrophoresis and transferred it to a Hybond ECL nitrocellulose membrane (Amersham, UK). We incubated the membrane with polyclonal rabbit anti-PPAR $\alpha$ (A/B domain) IgG (diluted 1:500) using horseradish peroxidase conjugated goat antirabbit IgG ( $1: 400)$ secondary antibody (Sigma) and visualised antigen/antibody complexes using the enhanced chemiluminescence detection system (ECL; Amersham). The membrane was blotted with $\beta$ - actin to confirm consistent loading and sample quality.

\section{Chemoprevention of polyps in $\mathrm{APC}^{\mathrm{Min}} /+$ mice}

We commenced C57BL/6J APC $\mathrm{APin}^{\mathrm{i}}+$ male and female mice, once weaned, on methylclofenapate $25 \mathrm{mg} / \mathrm{kg} /$ day (made up in safflower oil) $(n=13)$ or safflower oil alone $(n=14)$, which was administered by oral gavage. Animal experiments were performed according to EU regulations. C57BL/6J $\mathrm{APC}^{\text {Min }} /+$ mice were group housed, tap water was available ad libitum, and they were fed standard chow (Beekay, Humberside, UK) throughout the study. We determined time of sacrifice (14.3 \pm 0.4 weeks for treated and $13.3 \pm 0.3$ weeks for control mice; NS) by onset of clinically detected anaemia or $>20 \%$ body weight. At time of sacrifice, we flushed the entire intestine with saline and opened it lengthways. After fixing the tissue in formol calcium, we immersed it in thiazine dye (Baxter, UK) for five minutes before returning it to $70 \% \mathrm{C}_{2} \mathrm{H}_{5} \mathrm{OH}$ for 24 hours. Using this methodology, normal mucosa is stained blue allowing good differentiation from polyps (which remain unstained). We scanned each full length intestine on a $1 \mathrm{~mm}^{2}$ grid and, with specimens for comparison, highlighted the polyps manually and calculated their number. Finally, using the image analysis programme Qwinstandard (Leica, Milton Keynes, UK), we calculated the individual area of the large and small intestinal polyps, and the total area of abnormal and normal intestinal mucosa in each mouse.

\section{In vitro effects of PPAR $\alpha$ ligands \\ Cell culture}

We cultured human colonic adenocarcinoma (HCA7) cells (a kind gift from Dr S Kirkland, London ${ }^{25}$ in Dulbecco's modified Eagle's medium (Sigma) supplemented with $10 \%$ fetal calf serum, glutamine $(2 \mathrm{mmol} / \mathrm{l})$, penicillin $(100 \mathrm{U} / \mathrm{ml})$, streptomycin $(100 \mu \mathrm{g} / \mathrm{ml})$, and gentamicin $(0.05 \mathrm{mg} / \mathrm{ml})$ in a $5 \% \mathrm{CO}_{2}$ atmosphere at $37^{\circ} \mathrm{C}$.

\section{Transfection studies}

Using the cationic lipid transfection reagent Transfast (Promega) in a charge ratio of 1:2, we transfected HCA7 cells, which were $70-80 \%$ confluent, in serum free medium with a mix containing PPRE-tk-luc $(1.1 \mu \mathrm{g})$, pRL-CMV $(0.33 \mu \mathrm{g}$, as internal transfection control), and PPAR expression vector or empty pSG5 $(2 \mu \mathrm{g})$, where indicated. After a 60 minute incubation period, we supplemented the medium with $0.1 \%$ fetal calf serum and added pharmacological ligands for individual PPARs four hours later if appropriate. We calculated luciferase and renilla activity 40 hours after transfection using the DualLuciferase Reporter Assay System (Promega). We determined normalised luciferase activity which we plotted as fold activation relative to untreated cells. We performed all points in triplicate in at least two independent experiments.

\section{Measurement of linear cell growth and DNA synthesis}

We added methylclofenapate in DMSO, or DMSO alone, to subconfluent cultures of $(70 \%)$ HCA7 cells maintained in serum free medium for 24 hours. Two hours later, we stimulated mitogenesis by addition of $10 \% \mathrm{v} / \mathrm{v}$ fetal calf serum. We cultured the cells continuously in the presence of methylclofenapate $(100 \mu \mathrm{M})$ and assessed cell number at one, two, and five days.

We assessed DNA synthesis after 24 hours of exposure to ligand by measuring tritiated thymidine incorporation at 24 hours after a three hour pulse exposure to $\left[\mathrm{H}^{3}\right]$ thymidine (1 $\mu \mathrm{Ci} / \mathrm{ml})$. At the end of this period, the supernatant was aspirated and cells washed twice with $1 \times$ phosphate buffered saline (Invitogen, Paisley, UK) before fixing with methanolglacial acetic acid $(3: 1)(\mathrm{v} / \mathrm{v})$ for at least one hour at room temperature. Two further washes with $80 \%$ methanol were 
performed before lysing the cells with $1 \mathrm{ml}$ of $1 \mathrm{M} \mathrm{NaOH}$. Lysate $(900 \mu \mathrm{l})$ was then added to $10 \mathrm{ml}$ of scintillation fluid (Packard, Meriden, Connecticut, USA) and disintegrations per minute counted by liquid scintillation spectrometry (Wallace, Milton Keyes, UK).

Measurement of apoptosis and necrosis using flow cytometry: annexin $\mathrm{V}$ and propidium iodide staining We assessed rates of apoptosis and necrosis of HCA7 cells using flow cytometry, as described previously. ${ }^{26}$ After 12 hours of incubation with methylclofenapate, we treated cells with trypsin/EDTA, washed the resultant cell pellet in ice cold phosphate buffered saline, and resuspended cells in ice cold diluted binding buffer to concentrations of $10^{5} / 10^{6} \mathrm{cells} / \mathrm{ml}$. We next added $25 \mathrm{ng} / \mathrm{ml}$ of FITC conjugated annexin $\mathrm{V}$ and 10 $\mu \mathrm{g} / \mathrm{ml}$ of propidium iodide to cell suspension and, after 10 minutes of incubation in the dark, analysed cell staining using a fluorescence activated cell sorter (Becton Dickinson, USA)

\section{Cell cycle analysis}

We determined the proportion of nuclei in each phase of the cell cycle after exposure to methylclofenapate $(100 \mu \mathrm{M})$ using flow cytometry. Treated and control HCA7 cells were stained with propidium iodide $(0.5 \mu \mathrm{g} / \mathrm{ml})$ and fixed in $70 \%$ ethanol. We measured the relative DNA content of nuclei using a fluorescence activated cell sorter (Becton Dickinson). The proportion of nuclei in each phase of the cell cycle was determined using Cylchred analysis software.

\section{Statistics employed}

Expression levels of RNA and protein in tumour and normal mucosa were not normally distributed and therefore the Mann-Whitney $\mathrm{U}$ test was used. ANOVA and $t$ testing were used for other parameters.

\section{RESULTS \\ PPAR expression in non-malignant and neoplastic mucosa \\ RNA expression}

Using quantitative RNAse protection assays, we measured levels of PPAR $\alpha$ mRNA in non-malignant human colonic mucosal biopsy samples as $1.38(0.30)$ attamoles/ $\mu \mathrm{g}$ total RNA. Comparable values for PPAR $\gamma$ were 15.6 (10.4) attamoles $/ \mu \mathrm{g}$. When mRNA levels in neoplastic colonic tissues were compared with matched non-malignant mucosa, PPAR $\alpha$ was significantly decreased by $38.8 \%$ (median (interquartile range (IQR) 11.7-62.1\%); $\mathrm{p}=0.05$ ) (fig lA).

\section{Protein expression}

Using western blot analysis, we showed expression of both PPAR $\alpha$ and PPAR $\gamma$ in non-malignant human colonic mucosa. In malignant tissue there was a highly significant reduction in PPAR $\alpha$ protein levels (median reduction of $67.0 \%$ (IQR 55.2, $80.3 \%$ ); $p=0.001$ ) (fig 1B). There were no differences in $\beta$-actin levels between normal and malignant tissues.

\section{Activation of colonic epithelial PPARs}

In order to identify ligands capable of selectively activating PPAR $\alpha$ in colonocytes, PPRE- tk-luc (reporter gene) and individual PPARs were cotransfected into the human colon adenocarcinoma cell line HCA7 (fig 2A). Over expression of PPAR $\alpha$ in HCA7 cells increased PPRE-tk-luc activation significantly compared with the reporter gene activity of empty pSG5 vector $(p<0.001)$. Over expression of PPAR $\gamma$ or PPAR $\beta$ alone did not result in significant PPRE-tk-luc activation in the absence of ligand (fig $2 \mathrm{~A}$ ).

\section{Effect of ligands}

The known PPAR $\alpha$ ligand methylclofenapate further enhanced PPRE-tk-luc activation in cells cotransfected with
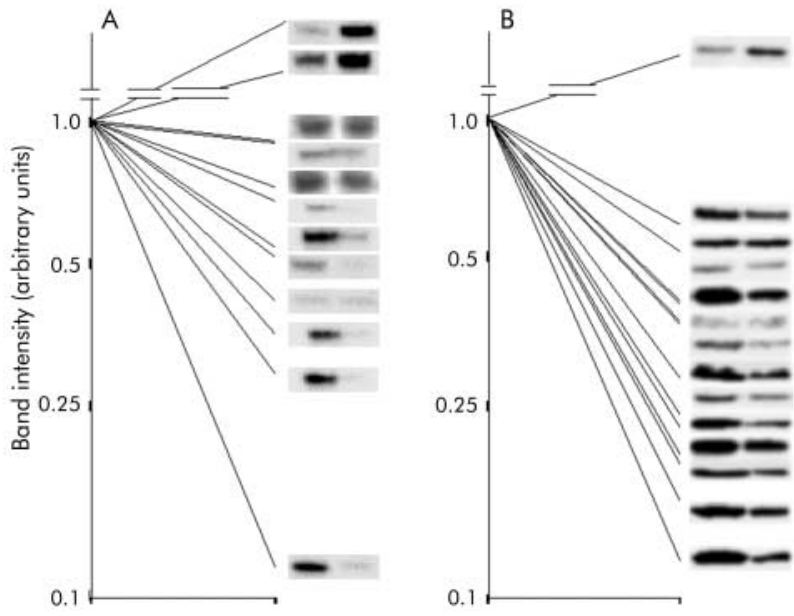

Figure 1 Peroxisome proliferator activated receptor $\alpha$ (PPAR $\alpha)$ mRNA and protein expression in non-involved and neoplastic human colon. (A) RNAse protection analysis of PPAR $\alpha$ mRNA expression in tumour samples and matched non-malignant colonic mucosa. RNA was hybridised with cRNA PPAR $\alpha$ probe, unhybridised RNA was digested with RNAse solution 1:70, and the protected fragments were resolved on a $6 \%$ urea/acrylamide/TBE gel. Data are shown as band intensity (arbitrary units) on a logarithmic scale, with individual bands (normal:tumour) to the side. (B) Western blot analysis of PPAR $\alpha$ protein expression in tumour samples and matched non-malignant colonic mucosa using rabbit antimouse PPAR $\alpha \lg G$ antibody. Data are shown as band intensity (arbitrary units) on a logarithmic scale, with individual bands (normal:tumour) to the side.

PPAR $\alpha$, over the concentration range $1-100 \mu \mathrm{M}$. Methylclofenapate $10 \mu \mathrm{M}$ stimulated $2.50(0.22)$-fold activation relative to no ligand (fig 3A). The better known PPAR $\alpha$ ligand Wyl4643 was less effective: Wyl4643 $10 \mu \mathrm{M}$ increased PPRE-tk-luc activation 1.4 (0.12)-fold when PPAR $\alpha$ was transfected (fig $2 B$ ). Although significant activation of PPAR $\beta$ and PPAR $\gamma$ was achieved with PPAR $\beta$ and PPAR $\gamma$ ligands, as appropriate (data not shown), methylclofenapate $10 \mu \mathrm{M}$ had no significant effect on PPAR $\beta$ or PPAR $\gamma$ activity (activation of $0.92(0.07)$ and $0.91(0.12)$ relative to no ligand) (fig $2 \mathrm{~A}$ ), confirming the potency and selectivity for PPAR $\alpha$ at this concentration.

\section{Functional responsiveness of endogenous PPARs in HCA7 cells}

We confirmed the functional responsiveness of endogenous PPARs in HCA7 cells by observing the ability of PPAR pharmacological ligands to activate a PPRE driven reporter gene (PPRE-tk-luc) transfected into these cells. Methlyclofenapate significantly induced reporter gene activity at concentrations $\geqslant 10 \mu \mathrm{M}$, indicating the presence of functionally active endogenous PPAR $\alpha$ in these cells (fig 3).

\section{Effect of methylclofenapate treatment on small and large intestinal polyp formation in $\mathrm{APC}^{\text {Min }} /+$ mice} We used methylclofenapate as the most potent and specific PPAR $\alpha$ activator from our transfection experiments to evaluate its effects on polyp formation in $A P C^{\text {Min }} /+$ mice. Fifteen mice (eight males, seven females) received methylclofenapate $25 \mathrm{mg} / \mathrm{kg}$ daily in safflower oil, and 14 (eight males, six females) received safflower oil alone. At sacrifice, there was a highly significant reduction in the total polyp burden in both the small intestine (median 18.67 (IQR 11.13, 26.84) $\mathrm{mm}^{2}$ to 9.9 (IQR $\left.4.88,13.21\right) \mathrm{mm}^{2} ; \mathrm{p}=0.003$ ) and the large intestine $(9.15$ (IQR $6.31,10.51) \mathrm{mm}^{2}$ to 3.71 (IQR $2.71,5.99$ ) $\mathrm{mm}^{2} ; \mathrm{p}=0.009$ ) (fig 4). These differences were seen in both male and female mice. Tumour burden/time also revealed significant differences for both the small and large intestine ( $p=0.006$ small intestine, $p=0.008$ large intestine). 

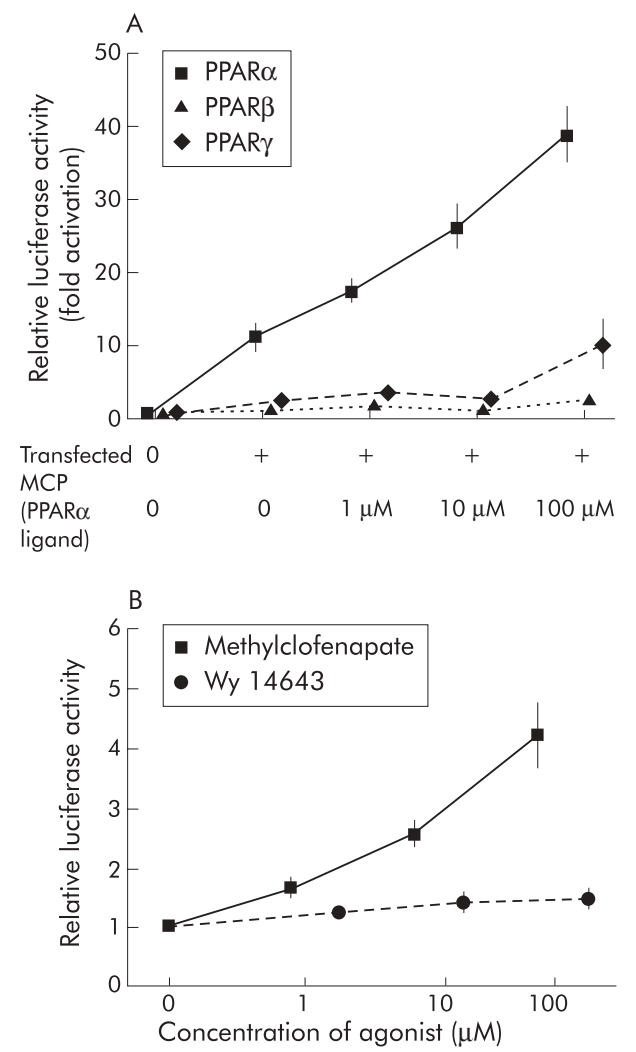

Figure 2 Selective activation of peroxisome proliferator activated receptor $\alpha$ (PPAR $\alpha$ ) by methylclofenapate. (A) Differential effects on transfected PPAR $\alpha$, PPAR $\beta$, and PPAR $\gamma$. HCA7 cells were transfected with $2 \mu \mathrm{g}$ of PPAR $\alpha$, PPAR $\gamma$, or PPAR $\beta$, expression vector or empty vector PSG5, PPRE-tk-luc $(1.1 \mu \mathrm{g})$, and pRL-CMV $(0.33 \mu \mathrm{g}$, as internal control), and exposed to the PPAR $\alpha$ ligand methylclofen apate (MCP) for 36 hours. Normalised luciferase activity is plotted as mean (SEM) fold activation relative to untreated cells transfected with empty vector PSG5. Over expression of PPAR $\alpha$, in HCA7 cells, in the absence of ligand, increased PPRE-tk-luc activation (23.2 (3.9)-fold) compared with reporter gene activation by pSG5 vector $(p=0.001)$. Methylclofenapate caused a further significant dose dependent increase in reporter gene activity. Over expression of PPAR $\gamma$ or PPAR $\beta$ alone did not result in significant PPRE-tk-luc activation. Methylclofenapate had no significant effect in the presence of transfected PPAR $\beta$ at all concentrations tested. It had no significant effect in the presence of transfected PPAR $\gamma$ at $\leqslant 10 \mu \mathrm{M}$, but caused a small increase in activity at $100 \mu \mathrm{M}$. (B) Comparative potency of PPAR $\alpha$ ligands as activators of PPAR $\alpha$. HCA7 cells were transfected with PPAR $\alpha$ expression vector $(2 \mu \mathrm{g})$, PPRE-tk-luc (1.1 $\mu g)$, and pRL-CMV $(0.33 \mu \mathrm{g}$, as internal control), and exposed to the

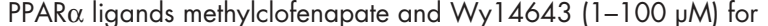
36 hours. In contrast with (A), normalised luciferase activity is plotted as mean (SEM) fold activation relative to cells that were transfected with PPAR $\alpha$ expression vector but not exposed to ligand.

Methylclofenapate activated PPRE-tk-luc more effectively than Wy 14643 at all concentrations used.

The reduction in tumour burden appeared mainly to be attributable to a reduction in individual polyp size in the large intestine (table 1 ) and to a reduction in polyp number in the small intestine (table 1).

\section{Effect of PPAR $\alpha$ on proliferation, apoptosis, and necrosis}

Fetal calf serum stimulated HCA7 cell proliferation, measured by $\left[{ }^{3} \mathrm{H}\right]$ thymidine incorporation, by approximately threefold. Methylclofenapate inhibited this serum stimulated thymidine incorporation in a dose dependent manner (fig 5A). Methylclofenapate caused a time and concentration dependent reduction in cell number (fig 5B), amounting to 39.7 (4.1)\% with $100 \mu \mathrm{M}$ by day $5(\mathrm{p}<0.001)$. The proportion of cells in the

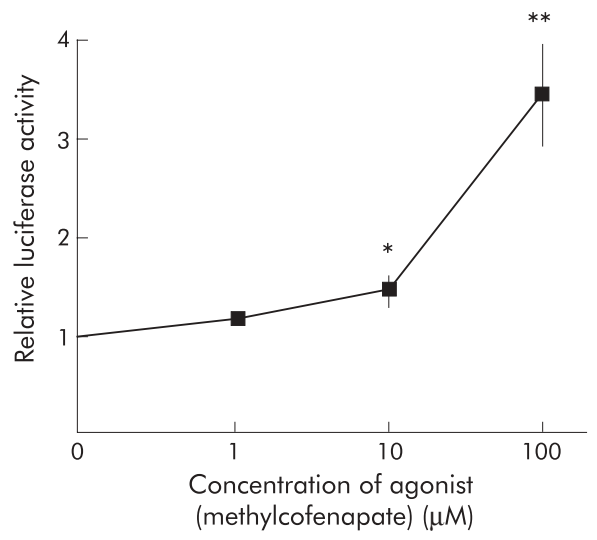

Figure 3 HCA7 cells were transfected with reporter plasmid PPRE-tk-luc $(1.1 \mu \mathrm{g})$ and PRL-CMV $(0.33 \mu \mathrm{g}$, as internal control) and exposed to the peroxisome proliferator activated receptor $\alpha$ (PPAR $\alpha$ ) ligand methylclofenapate or Wyl 4643 for 48 hours. Normalised luciferase activity is plotted as mean (SEM) fold activation relative to untreated cells. Methlyclofenapate and Wy14643 significantly induced reporter gene activity at concentrations $\geqslant 10 \mu \mathrm{M}$, indicating the presence of functionally active endogenous PPAR $\alpha .{ }^{*} p<0.05$, $\star * \mathrm{p}<0.001)$.
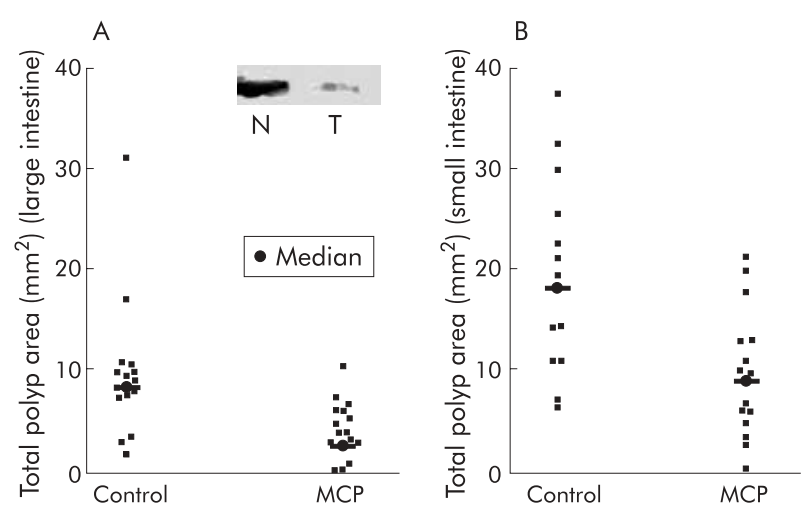

Figure 4 Peroxisome proliferator activated receptor $\alpha$ (PPAR $\alpha$ ) expression and reduction in total polyp area in $A P C^{\text {Min }} /+$ mice by treatment with the PPAR $\alpha$ activator methylclofenapate (MCP 25 $\mathrm{mg} / \mathrm{kg} /$ day). (A) Large intestine; (B) small intestine. Each point represents polyp area in an individual mouse. Median values are also shown. $\mathrm{N}$, normal; $\mathrm{T}$, tumour.

Gl phase of the cell cycle (62.2 (2.6)\% control; $63.5(1.6) \%$ with methylclofenapate $100 \mu \mathrm{M})$ and in G2 (11.8 (0.4)\% control; $13.8(3.0) \%$ with methylclofenapate $100 \mu \mathrm{M})$ did not differ with treatment. Methylclofenapate had no significant effect on annexin V (137.3 (31.6)\% of control values with methylclofenapate $100 \mu \mathrm{M}$ ) or propidium iodide (137.3 $(32.3) \%)$ staining.

\section{DISCUSSION}

In this study, we have shown a reduction in PPAR $\alpha$ expression in $89 \%$ of 26 colorectal cancers ( two of 12 in which mRNA was studied and one of 14 in which protein was studied). Methylclofenapate had a potent and relatively selective effect on epithelial PPAR $\alpha$ activity and reduced the polyp burden in both the small and large intestine of $\mathrm{APC}^{\text {Min }} /+$ mice. Functional studies suggested that PPAR $\alpha$ activation reduced epithelial proliferation with no effect on apoptosis or necrosis. Our results as a whole strongly support a central role for PPAR $\alpha$ activation in preventing neoplastic transformation or growth.

The role of PPAR $\alpha$ in non-malignant colon is uncertain. It is present in normal human colonic mucosa from an early stage of development, suggesting its involvement in the establishment of lipid metabolism. ${ }^{27}$ Its pattern of expression changes 
Table 1 Differences in individual polyp area and polyp number in treated and control APC Min $/+$ mice at the time of sacrifice

\begin{tabular}{|c|c|c|c|c|}
\hline & \multicolumn{2}{|l|}{ Large intestine } & \multicolumn{2}{|l|}{ Small intestine } \\
\hline & Control & Treated & Control & Treated \\
\hline Individual polyp area $\left(\mathrm{mm}^{2}\right)$ & $1.123(0.690,1.786)$ & $0.848(0.570,1.265)^{* *}$ & $0.710(0.518,1.050)$ & $0.701(0.496,0.879)$ \\
\hline $\begin{array}{l}\text { Individual polyp area }\left(\mathrm{mm}^{2}\right) \\
\text { (corrected for time of death) } \dagger\end{array}$ & $0.085(0.046,0.121)$ & $0.065(0.042,0.089)^{*}$ & $0.049(0.037,0.071)$ & $0.051(0.037,0.069$ \\
\hline Polyp No. & $6.5 \quad(4.1,10.0)$ & $4.0 \quad(1.0,7.0)^{*}$ & $24.0 \quad(15.8,30.3)$ & $13.0(5.0,7.0)^{* *}$ \\
\hline $\begin{array}{l}\text { Polyp No (corrected for time of } \\
\text { death) } t\end{array}$ & $0.425(0.308,0.630)$ & $0.308(0.077,0.540)$ & $1.60(1.080,2.070)$ & $0.920(0.539,1.167)^{* *}$ \\
\hline
\end{tabular}
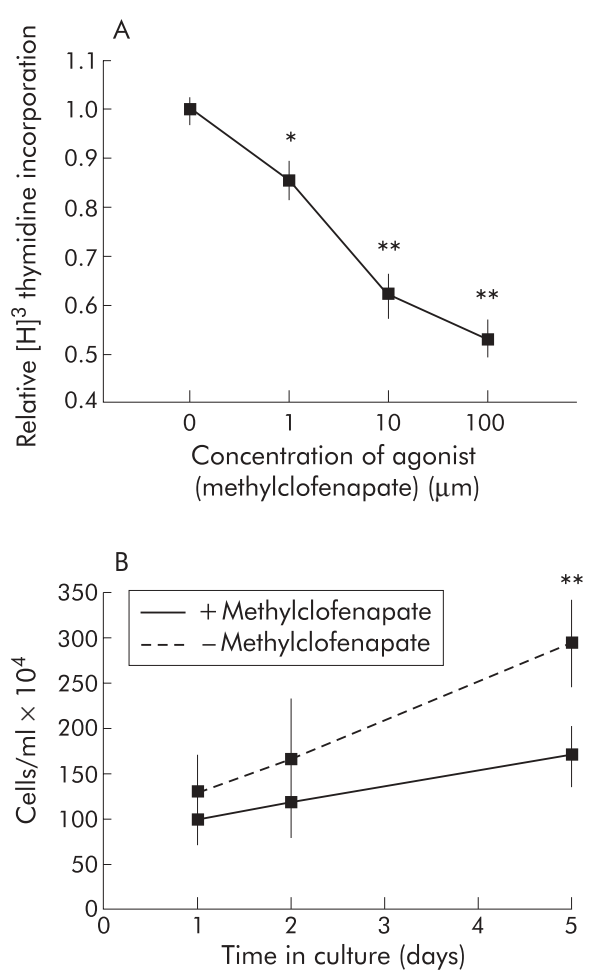

Figure 5 Effect of methylclofenapate on: (A) serum stimulated $\left[{ }^{3} \mathrm{H}\right]$ thymidine incorporation; (B) HCA7 linear cell growth in the presence or absence of methylclofenapate $100 \mu \mathrm{m}$. There was a significant reduction in thymidine incorporation after 24 hours of exposure to methylclofenapate, indicating an effect on DNA synthesis, and a significant reduction in cell number by day 5 $\left({ }^{*} p<0.05,{ }^{*} p<0.001\right)$.

with progression through embryogenesis, becoming increasingly confined to the nuclei of epithelial cells on the surface of villi, with adult mucosa exhibiting expression only in these cells. ${ }^{27}$ In this study, we have shown that PPAR $\alpha$ mRNA and protein expression become substantially depressed during carcinogenesis. The previous demonstration of reduced peroxisomal oxidative activity in neoplastic colonic mucosa ${ }^{28}$ suggested the functional significance of reduction in PPAR $\alpha$ expression levels that we observed. There was a substantially greater reduction in protein relative to mRNA expression, suggesting that repression of PPAR $\alpha$ expression in human colorectal cancer may possibly occur at both the transcriptional and post-transcriptional levels. A reduction in PPARo protein expression was also observed in tumour tissue in $A P C^{\text {Min }} /+$ mice.

We confirmed the presence of functionally active endogenous PPAR $\alpha$ in colon cancer derived cell lines. The level of PPRE driven luciferase activation achieved by PPAR $\alpha$ ligands was similar to that previously reported with PPAR $\gamma$ ligands in colon cancer cell lines. ${ }^{29}$ The substantial stimulation of PPRE containing reporter gene expression achieved when PPAR $\alpha$ expression vector was transfected in the absence of ligand suggests the presence of endogenous ligand(s), as has been determined previously for other cell lines. ${ }^{30}$ Against this substantial background of endogenous activation, which has previously been reported, ${ }^{30}$ methylclofenapate further increased transactivation by PPAR $\alpha$ in a dose dependant fashion, confirming the potency of this isoform.

Although methylclofenapate may have pleiotrophic antitumour effects, this compound is a potent and selective PPAR $\alpha$ agonist, and it is likely that the polyp reduction demonstrated in $\mathrm{APC}^{\text {Min }} /+$ mice occurred, at least in part, due to PPAR $\alpha$ activation. Methylclofenapate is clearly an efficacious activator of PPAR $\alpha$, although some loss of selectivity occurs at high concentrations. As PPAR $\gamma$ selective ligands have been shown in the $\mathrm{APC}^{\mathrm{Min}} /+$ mice model to have an opposite effect on colorectal carcinogenesis, ${ }^{12}{ }^{13}$ the effects seen in our study are more likely to be PPAR $\alpha$ specific. This is supported by the earlier observation that bezafibrate (a less specific PPAR $\alpha$ ligand) inhibits the formation of aberrant crypt foci, which are cited as precursor lesions for colon carcinoma, in rats. ${ }^{19}$ Downstream effects of PPAR $\alpha$ activation and their subsequent influence on tumour progression remain to be determined.

Our data suggest that PPAR $\alpha$ activation by methylclofenapate significantly reduces serum stimulated mitogenesis, as measured by tritiated thymidine incorporation and linear cell growth. Preclinical toxicity studies suggest that the concentrations of methylclofenapate achieved in the animal study were equivalent to the higher concentrations employed in our in vitro work..$^{31}$ Methylclofenapate had no effect on cell death, as assessed by annexin $\mathrm{V}$ or propidium iodide staining or trypan blue exclusion. While annexin $\mathrm{V}$ staining may indicate processes other than apoptosis, the absence of any induction in annexin $\mathrm{V}$ or propidium iodide staining means that PPAR $\alpha$ activation had no effect on any of the processes, including apoptosis, that are associated with such staining. One inference is that, while NSAIDs have been shown to compete with PPAR ligands, ${ }^{11}$ it is likely that they increase apoptosis via effects on PPAR $\alpha$. How PPAR $\alpha$ activation inhibits cellular proliferation is not clear. One possibility is that it occurs through effects on $\beta$ oxidation ${ }^{32}$ as PPAR $\alpha$ is a key transcription factor in the regulation of both peroxisomal and mitochondrial $\beta$ oxidation. ${ }^{20}$ The fact that MCP treatment results in a reduction in polyp size rather than number in the colon is intriguing, particularly as it contrasts with effects seen in the small intestine (where polyp number is reduced). It suggests that in the colon, MCP reduces polyp cell proliferation whereas in the small intestine it may affect actual tumour initiation. These apparent tissue specific effects of MCP may be attributable to differences in PPAR $\alpha$ expression, as demonstrated in the small and large intestine.

Although toxicity studies have led to termination of the development of methylclofenapate, ${ }^{31}$ our studies suggest that 
identification and investigation of other PPAR $\alpha$ ligands as possible anticancer agents would be justified. Moreover, in view of the importance of dietary fat in the development of colorectal cancer and the key role of PPARs in fat metabolism, our data may assist in both understanding the process of malignant transformation and highlighting potential therapeutic strategies.

\section{ACKNOWLEDGEMENTS}

The authors acknowledge the financial support of the Medical Research Council, UK.

\section{Authors' affiliations}

L Jackson, S A Watson, T Morris, J A Smith, C J Hawkey Wolfon Digestive Diseases Centre, University of Nottingham, UK W Wahli, L Michalik, Institut de Biologie Animale, Universite de Lausanne, Batiment de Biologie, Lausanne, Switzerland

K Anderton, A Bennett School of Biomedical Sciences, Queen's

Medical Centre, Nottingham, UK

D R Bell School of Life Sciences, University of Nottingham, UK

\section{REFERENCES}

1 Boyle $\mathbf{P}$, Langman MS. ABC of colorectal cancer epidemiology. BM 2000;321:805-8.

2 World Cancer Research Fund/American Institute for Cancer Research. Food Nutrition and the Prevention of Cancer: a Global Perspective. Washington, BANTA Book Group USA, 1997.

3 Fearon ER, Vogelstein B. A genetic model for colorectal tumorigenesis. Cell 1992;61:759-67.

4 Kinzler KW, Vogelstein B. Lessons from hereditary colon cancer. Cell 1996;87:159-70.

5 Isseman I, Green S. Activation of a member of the steroid hormone receptor superfamily by peroxisome proiferators. Nature 1990:347:645-50.

6 Meade E, Mclntyre TM, Zimmerman G, et al. Peroxisome proliferators enhanced cyclooxygenase-2-expression in epithelial cells. J Biol Chem 1999;274:8328-34

7 Staels B, Koenig W, Habib A, et al. Activation of human aortic smooth-muscle cells is inhibited by PPAR alpha but not by PPAR gamma activators. Nature 1998:293:790-3.

8 LehmannJM, Lenhard JM, Olivier BB, et al. Peroxisome proliferator-activated receptors alpha and gamma are activated by indomethacin and other non-steroidal anti-inflammatory drugs. J Biol Chem 1997;272:3406-10.

9 Yu K, Bayona W, Kaleb CB, et al. Differential activation of the peroxisome proliferator activated receptors by eicosanoids. I Biol Chem $1995 \cdot 270: 23975-83$

10 Forman BM, Tontonoz P, Chen J, et al. 15-Deoxy-delta 12, 14-prostaglandin $\mathrm{J} 2$ is a ligand for the adipocyte determination factor PPAR gamma. Cell 1995;83:803-12.

11 Tong-Chuan HE, Chan TA, Vogelstein B, et al. PPAR delta is an APC-regulated target of nonsteroidal anti-inflammatory drugs. Cell 1999.99:335-45.

12 Lefebrve A-M, Najib J, Dewreumaux P, et al. Activation of the peroxisome proliferator activated receptor gamma promotes the development of colon tumours in C57BL/6J-APC Min $/+$ mice. Nat Med 1998:4:1053-7.
13 Saez E, Tontonoz P, Nelson MC, et al. Activation of the nuclear receptor PPAR gamma enhance colon polyp formation. Nat Med 1998:4:1058-61.

14 Auboeuf D, Rieusset J, Fajas L, et al. Tissue distribution and quantification of the expression of mRNAs of PPARs and liver alpha receptor in humans. Diabetes 1997:46:1319-27.

15 Takahashi $M$, Minamoto T, Yamashita N, et al. Effect of docosahexaenoic acid on azoxymethane-induced colon carcinogenesis in rats. Cancer Lett 1994;83:177-84.

16 ligo $M$, Nakagawa $T$, Ishikawa $C$, et al. Inhibitory effects of docosahexaenoic acid on colon carcinoma 26 metastasis to the lung. $\mathrm{Br}$ J Cancer 1997;75:650-5

17 Beck SA, Smith KL, Tisdale M. Anticachectic and antitumor effect of eicosapentaenoic acid and its effect on protein turnover. Cancer Res 1991;51:6089-93.

18 Anti M, Marra G, Armelao F, et al. Effect of omega-3 fatty acids on rectal mucosal cell proliferation in subjects at risk for colon cancer. Gastroenterology 1992;103:883-91.

19 Tanaka T, Kohno H, Yoshitani S, et al. Ligands for peroxisome proliferator activated- receptors $\alpha$ and $\gamma$ inhibit chemically induced colitis and formation of aberrant crypt foci in rats. Cancer Res $2001 ; 61: 2424-8$

20 Dreyer C, Krey G, Keller H, et al. Control of the peroxisomal-oxidation pathway by a novel family of nuclear hormone receptors. Cell 1992:68:879-87.

21 Tugwood JD, Issemann I, Anderson RG, et al. The mouse peroxisome proliferator activated receptor recognizes a response element in the $5^{\prime}$ flanking sequence of the rat acyl CoA oxidase gene. EMBO J 1992:11:433-9.

22 Chomczynski P, Sacchi N. Single step method of RNA isolation by acid guanidium thiocyanate-phenol-chloroform extraction. Anal Biochem 1987; 162:156-9

23 Harley CB. Hybridization of oligo (dT) to RNA on nitrocellulose membrane. Gene Anal Tech 1987:4:17-22.

24 Fajas $L$, Auboeuf $D$, Raspe $E$, et al. The organisation, promoter analysis and expression of the human PPAR gamma gene. J Biol Chem 1997; 272:18779-89.

25 Kirkland SC. Dome formation by a human colonic adenocarcinoma cell line (HCA7). Cancer Res 1985;45:3790-5

26 Vermes I, Haanen C, Reuttelingsperger CPM. A novel assay for apoptosis: Flow cytometric detection of phosphatidylserine expression on early apoptotic cells using fluorescein labelled Annexin V. J Immunol Method 1995:180:39-52.

27 Huin C, Coirriveau L, Bianchi A, et al. Differential expression of peroxisome proliferator-activated receptors (PPARs) in the developing human fetal digestive tract. J Histochem Cytochem 2000;48:603-1 1 .

28 Cable S, Keller JM, Colin S, et al. Peroxisomes in human colon carcinomas. A cytochemical and biochemical study. Virchows Archiv B Cell Pathol 1992;62:221-6.

29 Brockman JA, Gupta RA, Du Bois RN. Activation of PPAR gamma leads to inhibition of anchorage-in dependant growth of human colorectal cancer cells. Gastroenterology 1998:115:1049-55.

30 Juge-Aubry C, Pernin A, Favez T, et al. DNA Binding properties of peroxisome proliferator activated receptor subtypes on various natural peroxisome proliferator response elements. J Biol Chem 1997:272:25252-9.

31 Tucker MJ, Orton TC. Comparative Toxicology of Hypolipadaemic Fibrates. London: Taylor and Francis Ltd, 1995:23-58.

32 Gervois P, Torra IP, Fruchart JC, et al. Regulation of lipid and lipoprotein metabolism by PPAR activators. Clin Chem Lab Med 2000:38:3-1 1. 